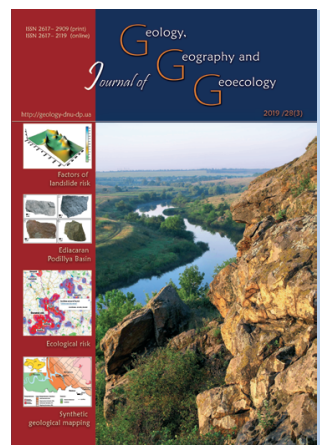

S. M. Shevchuk
Journal of Geology. Geography and Geoecology

Journal home page: geology-dnu-dp.ua
ISSN 2617-2909 (print)

ISSN 2617-2119 (online)

Journ.Geol.Geograph.

Geology,

28(3), 546-553.

doi: $10.15421 / 111951$

\title{
Human geography in Ukraine: problems of development and priority research directions
}

\section{S. M. Shevchuk}

\section{Poltava V. G. Korolenko National Pedagogical University, Poltava,Ukraine, S_Sevchuk@online.ua}

Received: 20.02.2019

Received in revised form: 06.03.2019

Accepted: 17.04.2019

regarding the improvement of the socio- territorial organization in Ukraine. The article analyses the different functional aspects of development of human geography in Ukraine. Among the main problems that hinder the development of scientific schools, and therefore the science in general, are the following: individualized activity of scientific schools without specific purpose, partial realization of their contribution to all-school social geography, and contribution to the world of science; the problem of definition, which is associated with the use of simultaneous usage of different terms for the science ; «economic and social geography», «socio-economic geography», «social geography»; the problem of social differentiation, geography and lack of a pivotal system of logically completed laws of science that could integrate different paradigms and research areas; lack of implementation of applied science functions and etc. Considerable attention is paid to the prospects of comprehension of human geography related to improvement of the theoretical basis in accordance with the realities of the beginning of XXI century, emphasis is placed on applied aspects of science and avoidance of pointless abstraction. The strategic goal of socio-geographical science is the determination of economic, demographic, social, political and environmental capacities of the geographic shell, justification of rational parameters of regional and global nature management, identification of the main trends of technological, sectoral and territorial development of the economy of Ukraine and its regions.It is proved that the main tasks of the science are also studies of the quality of life of the population; improvement of the structure of production and its transfer to an innovative level; definition and achievement of the optimal social, functional-branch and territorial structure of the economy; optimizing the structure of economic, social, political and other ties. At the regional and local levels, priorities include the problems of nature use and nature conservation, the development of depressed regions, the justification and implementation of regional economic, social, demographic and environmental policies. The key to solving these problems from the methodological point of view is the substantiation of the general theory of regional studies taking into account the diversity of the territorial organization of society.

Keywords:human geography, Ukraine, territorial organization of society, problems of science development, scientific directions, prospects of development of the science.

\section{Суспільна географія в Україні: проблеми розвитку та пріоритетні напрями досліджень}

\section{С. М. Шевчук}

Полтавський національний педагогічний університет імені В. Г. Короленка, Полтава, Україна, S_Sevchuk@online.ua

\begin{abstract}
Анотація. Визначено проблеми розвитку наукових шкіл суспільної географії в Україні. Показано, що сучасна суспільна географія в Україні-це методологічно сформована наука із власним теоретичним і методичним апаратом, який у найтеперішніх умовах має бути спрямований на розв'язання прикладних завдань щодо вдосконалення територіальної організації суспільства в Україні. проаналізовано різні функціональні аспекти розвитку суспільної географії в Україні. Серед основних проблем, що перешкоджають розвитку науки $є$ : індивідуалізована діяльність наукових шкіл без цільового призначення часткової реалізації iii внеску в світову суспільну географію; проблема ідентичності, пов'язана з одночасним використанням назви «економічна і соціальна географія», «соціально-економічна географія», «суспільна географія»; проблеми диференціації географії та відсутності системи завершених законів науки, які могли б інтегрувати різні парадигми та напрямки досліджень; відсутність реалізації прикладних функцій науки тощо. Вирізнені проблеми розвитку суспільної географії: ігнорування самим суспільством результатів досліджень суспільно-географічної науки; розпорошення суспільно-географічних студій за новими напрямами досліджень; проблема самоідентифікації та диференціації науки; нереалізованість їі прикладної функції тощо. Стратегічною
\end{abstract}


метою суспільно-географічної науки окреслено визначення економічної, демографічної, соціальної, політичної та екологічної ємності географічної оболонки, обгрунтування раціональних параметрів регіонального і глобального природокористування, виявлення основних тенденцій технологічного, галузевого й територіального розвитку господарства України і їі регіонів. Доведено, що головними завданнями науки також є дослідження проблем якості життя населення; удосконалення структури виробництва та переведення його на інноваційний рівень; визначення та досягнення оптимальної соціальної, функціональногалузевої й територіальної структури господарства; оптимізації структури економічних, соціальних, політичних та інших зв'язків. На регіональному й локальному рівнях - проблеми природокористування й охорони природи, розвитку депресивних регіонів, обгрунтування й реалізація регіональної економічної, соціальної, демографічної та екологічної політики. Запорукою розв'язання цих проблем з методологічного погляду є обгрунтування загальної теорії регіонознавства 3 урахуванням різноманіття територіальної організації суспільства.

Ключові слова: суспільна географія, Украӥна, територіальна організація суспільства, проблеми розвитку науки, наукові напрями, перспективи розвитку науки.

Introduction. The priority directions of fundamental scientific research on the most important problems of the development of scientific and technical, socio-economic, socio-political, human potential for ensuring the competitiveness of Ukraine in the light of sustainable development are identified at the legislative level. The problems of rational nature management today are successfully solved by the scientists specializing in the field of social geography. At the same time, it is necessary to outline the problems of development of human geography in Ukraine and to identify the priority directions of its further research in order to increase the status of human geography in Ukrainian society, primarily due to the effectiveness of research.

Modern human geography in Ukraine, according to K. Mezentsev (K. Mezentsev, 2010), «is at a crossroads», and the choice of the further path of the science's development depends on the essential awareness of its practitioners. One of the possible directions will involve conservatism of theory and methodology, self-satisfaction at achievements made, and the other will promote innovation and scientific research, one of them is oriented to the depth of the industrial society, the other towards the information society, one of them will lead to self-isolation, the other will ensure integration into world social geography.

During recent years of the $\mathrm{XX}$ - in the beginning of XXI century a number of works on methodology and theory of geography were published, articles that revealed problems and the development prospects of human geography in Ukraine, analysis of the state and strategy of the science's development, awareness of the mission and trends of human geography in the context of the latest challenges and demands of society,. The search for a place, role and the development prospects of the science was a key theme of the Ukrainian Geographical Society's congresses («Ukraine and Global Processes: Geographic Dimension», Lutsk, 2000; «Ukraine: Geographical Problems of Sustainable Development», Chernivtsi, 2004; «Geography in the Information Society», Kyiv, 2008; «Ukraine: Geography of Goals and Opportunities», Kyiv, 2013; «Ukrai- nian Geography: Modern Challenges», Vinnytsia, 2016). Among these works, it is especially worthwhile to highlight the research by M. Pistun «The Tasks of Human Geography in the Context of the Problems of Ukraine's Regional Development» (2003), «On New Development Directions of Socio-Geographical Research in Ukraine» (2005), K. Nemets «Human Geography: Problems and New Horizons» (2006), M. Bahrov «The Paradox of Unclaimed Geography and Its Development Trends» (2006), «The New Paradigm of Geography in the Information World»(2008),Y. Oliinyk «Tasks of Economic and Social Geography in the Information Society» (2008), L. Rudenko «The Problem of the Formation and Use of Spatial Data and the Problem of Geography» (2008), O. Shablii «The Imperative of Ukrainocentrism in National Geographic Science» (2008), K. Mezentsev «Problems and Prospects of Ukrainian Human Geography of the XXI Century» (2008),Y. Oliinyk and A. Stepanenko «The Development Strategy of Economic and Social Geography» (2009), E. Maruniak «Modern European Geography: Directions of Development» (2010), M. Bahrov, L. Rudenko and I. Chervaniov «New» Geography in Ukrainian Realities: Mission and Trends»(2012), O. Topchiiev, V. Nudelman and L. Rudenko «New Challenges and Inquiries of Geography (Ukrainian Aspect)»( 2011), L. Nemets «Modern Social Geography: Analysis of the Situation, Problems and Prospects» (2012), M. Bahrov, L. Rudenko, I. Chervaniov «Progress of New Geography» - Essence and Purposes» (2012), P. Masliak «Public Geography: A Scientific Paradigm Shift in the XXIst Century»(2013), M. Dnistriansky «On the Need for a New Look at the Subject Human Geography» (2016), O. Topchiiev «Geography Subject Area and Its Modern Methodological Transformations» (2016) and others.

The basic generalizations for the future development of human geography in Ukraine are presented in the studies of L. Rudenko and M. Bahrov. They determine its transition to a qualitatively new stage of information geography, which studies the distribution of new knowledge and information, as well as the 
formation, storage, processing and interpretation of specific geospatial-time coordinates using GIS technologies. The researchers identified key aspects of the current state of science in Ukraine and outlined the prospects of its development (Bahrov, 2005; Rudenko, 2006): geography has its own field of research that is not overlapped by any other science; geographic studies integrate new knowledge and information about space due to the high significance of the concepts of location, goal and development resources; Geography in Ukraine develops scientific concepts and ways of their implementation, striving to acquire the status of economic «pole of growth», in order to become, together with it, a «new» geography in the forefront of sciences that provide sustainable development.

O. Topchiev (Topchiev,2012), analyzing public requests for geographic science and the challenges that cause the formation of new approaches, concepts and trends in its theory and methodology, states that some of them have become recognized and spread, have become the latest paradigms of modern geography (geo-information, geo-planet paradigms). The scientist emphasizes that geographers should more actively develop a general-scientific intentional paradigm, which provides a new methodological understanding of the key problem for geography - the problem of interaction between society and nature.

Covering the tendencies of development of economic and social geography, the evolution of the subject of its study, the discipline's objectives in the context of the globalization of world-system connections, Y. Oliinyk (Oliinyk, 2009) is exploring the strategic directions of the development of fundamental research in economic and social geography; this entails determining the strategic directions of the science's formation of a unified planetary system, in which, according to the scientists, a significant role should belong to economic and social geography, intended to create the basis for the development and functioning of humanity in qualitatively new conditions.

O. Shablii justifies the principles and directions of the development of human geography in a rather interesting way, namely through the imperative of Ukrainocentrism as a means of intensifying the development of the science, which involves focusing the study of Ukraine as a natural-, demo-, social-, economic-, and politico-geographical isolation in the context of different levels of geospatial organization of the earth's nature and human civilization. The imperative of Ukrainocentrism also requires the removal of the semantic units of Soviet ideology's (Shablii, 2008).

According to $\mathrm{K}$. Mezentsev, the challenges of modern human geography are related to the change in the methodology of socio-geographical research, which is determined by the analysis of spatial aspects of various transformational processes, the evolution of economic, socio-cultural, political activity of the population; justification of the prospects of regional development in view of the new factors; studying the processes of social polarization of the population, regional social security, spatial distribution of social problems and threats; combining quantitative and qualitative methods of research (traditional methods of spatial analysis, GIS analysis, geographic and mathematical modeling, on the one hand, and methods aimed at determining perceptual characteristics of regions, identifying regional stereotypes, regional selfidentification of the population, on the other), using new methods of research (nonlinear modeling, neural networks, fractal geometry, fuzzy set theory, etc.).

In 2011, the Institute of Geography of the National Academy of Sciences of Ukraine held a scientific seminar «Geographical science in the new socio-economic conditions of development of Ukraine», which identified the conceptual problems of functioning socio-geographical science in Ukraine. It is no coincidence that the XII Congress of the Ukrainian Geographical Society (2016) took place under the slogan «Ukrainian Geography: Modern Challenges», it paid great attention to the contemporary tasks of the development of sociogeographical science. A detailed analysis of the reports on the problems of the science which were made at the congress was carried out in the article by Y. Oliinyk (Oliinyk, 2016). The author acquainted readers with the views of national scholars on the problems and prospects of the development of social geography.

The most interesting, in our opinion, are the researches by L. Rudenko, O. Topchiiev, P. Masliak, V. Oleschenko, S. Bortnik, A. Gudzevych and M. Dnistrianskyi. L. Rudenko stressed that geographic research should focus on practical activities in the regions (regional development strategies, various types of territorial planning, etc.) regarding the mechanisms of implementing the principles of balanced development; intensify the work of the scientific geographic schools for the formation of innovation-oriented economy; take part in a strategic environmental analysis. O. Topchiev proposed in the geographical sciences along with two traditional branches (natural and social) to form a new direction - the development of theoretical and methodological principles of functioning of the Earth's landscape as a holistic and complex socio-economic natural system (Topchiiev, 2016).P. Masliak defined the priority task of modern geography - modeling the territory in accordance with scientific geographical representations about its harmonious and effective development; this direction, in the opinion of the scientist, will ensure 
the unity of geographical science (Masliak, 2016). V. Oleshchenko proposed to introduce a new specialty «theory of geography» for those studying towards scientific degrees (Oleshchenko, 2016). In our opinion, the specialty «theory and history of geography» would be more optimal, like a similar scientific specialty in other fields of knowledge. S. Bortnik, together with other scientists, determined the objective of geography in Ukraine in the development of new scientific and applied areas based on the use of world experience of spatial development, geo-planning, landscape development of the territory and modeling in the system of multi-level management. A. Gudzevych analyzed the space-time paradigm of science and proposed to develop national geography as a science of a single planetary system, paying particular attention to geo-space and geo-environment (Gudzevich, 2016). M.Dnistrianskyi raised the issue of the need for a new substantiation of the subject of human geography as a humanitarian geographic science on geospatial development, placement, vital activity and interaction of human communities and the formation under their influence of cultural landscapes. According to the scientist, the combination of human communities as special territorial-organized social entities and cultural landscapes of the Earth's surface provides the substantive filling of the socio-geographical world and creates the framework of geographical space in general. According to this approach, M. Dnistrianskyi proposed that human geography be considered not as a set of social spatial forms of social objects, but as a humanitarian geography, in the epicentre of which the geographic world of human societies is located (Dnistrianskyi, 2016).

Some of the reports were devoted to the methodological problems of applied socio-geographical research and new directions of development of the science, namely: geography of tourism (G. Balabanov, O. Liubitseva, M. Malska, L. Zelenska, O. Kolotukha), geography of the quality of life of the population (I. Hukalova), military geography (Y. Ivakh), methods of multidimensional analysis (K. Niemets, L. Niemets, K. Sehida), geopolitical paradigm and political geography (Y. Oliinyk, A. Stepanenko, B. Yatsenko), territorial planning (H. Pidhrushnyi) and others.

The purpose of the paper.The generalizing idea in the works of most modern Ukrainian scholars is the recognition and justification of human geography as a methodologically formed science with its own theoretical and methodical apparatus, which in the present conditions must first of all be directed at solving applied problems concerning the improvement of the territorial organization of society in Ukraine. At the same time, the theoretical foundations of the science, first of all, through the introduction of new approaches, concepts, etc, need a certain development as well.The purpose of this paper is to determine the problems of the development of human geography in Ukraine and to formulate promising directions for its research.

Results and discussion. The factors determining the problems of contemporary human geography are the ignoring of the results of research of spatial science by society itself («consumer society»), as well as the extension of socio-geographical research into new areas, especially those that are formed on the frontier with other sciences (regional economics, regional demography, regional sociology, regional policy, etc.). Using the subject of human geography and applied aspects which are contiguous with social science disciplines, artificial creation of new scientific fields, as well as sciences (regional economics, regional cultural studies, etc.) can lead to the transformation of fundamental science into the method of studying these sciences.Public geography, which is part of the system of geographical sciences, is, of course, a component of the wider system of Earth Sciences, but its successful development is impossible without close links with social sciences. At the same time, in recent years, the intensification of such connections has been observed.Modern connections of human geography with economics, sociology, political science, demographics, computer science and management lead to strengthening of the applied direction in geography. Within the framework of the implementation of the applied science function, the participation in evaluative, forecasting works and territorial planning, programming and estimating becomes important. It is by this very point that human geography as the only science based on spatial methodology should be opposed to the directions of regional studies of social sciences.

While highly appreciating the scientific achievements of human geography in Ukraine, it should be noted that in today's conditions there is a sharp decline in interest in solving its theoretical problems, developing new concepts, modernizing the formed theories. In this case, from the side of social geography, the practice of fragmentary incursions into the field of the adjacent social disciplines is expanding. Modern human geography in Ukraine has to win its monopoly on spatial research, thus restoring its position in the system of sciences.

The analysis of the problems of human geography development in Ukraine gives grounds for determining the problems of its functioning. The further development of human geography in Ukraine depends on the operational actions of modern scientists. Among the main problems which restrain the development of 
social geography, one should note the following.

1. Individualization of the activities of scientific schools without formulating the concrete goal of realizing its contribution to the all-Ukrainian school of social geography, and through the latter, to world science. The lack of a tradition of coordination and consolidation of socio-geographical schools has resulted in the dissociation of the socio-geographical community and the inconsistency of scientific research. Despite having in its arsenal extremely important scientific achievements, as well as practical results of research on society's territorial organization, public geography in Ukraine remains almost non-integrated into world science, and dialogue with other national schools is practically absent. Scientific knowledge is known to be universal, but national specificity in socio-geographical research should be manifested even when it comes to fundamental theoretical problems.In such a situation, within each of the directions of human geography there are points of intersection with various adjacent social sciences, and intersection areas with the scientific schools of these social sciences. As a result, there is a further differentiation of socio-geographical science. That is why the main direction of the development of science should be the synthesis of the achievements of a modern school of human geography with its fundamental development of an integrated approach to studying the territory, on the one hand, and the modern theory of synergetics of large systems in relation to spatial-dynamic structures, on the other. We see another way of overcoming this problem in the coordination of the subjects of research under the auspices of the Institute of Geography of the National Academy of Sciences.

2. Over the past decades, the problem of selfidentification of human geography has increased. Until 2015, it was defined only by the incongruity between the name of the science in the scientific environment of Ukrainian geographers as «social geography» and the official name of the vast majority of university departments and the specialty of the graduates of scientific degrees as «economic and social geography». The introduction of a new list of academic fields and specialties in 2015, according to which higher education graduates are trained, means that social (economic and social) geography is dissolved in the science system under the name«Earth Sciences».Officially, the name «social geography» has long been used only in the name of one department of the Institute of Geography of the National Academy of Sciences (the Department of Social and Geographical Research). Until recently, Ukraine's only department of «social geography» existed at the Lesya Ukrainka Eastern European National University. Simultane- ously among scientists of Ukraine different names are used («economic geography», «socio-economic geography», «human geography»), and when writing scientific works, in particular theses, the preference is given to the name «human geography».

3. The process of internal differentiation of human geography in Ukraine is still far from its completion, since not all elements that form the territorial organization of society have become objects of research. The process of internal integration of human geography influences its diversification as well. The processes of differentiation and integration of human geography directly relate to the development of its theory, on the one hand, the formation of the social sciences' branch theory, and on the other - the development of the general theory of science on the whole. Modern human geography is characterized by the absence of a logically complete system of scientific laws, the predominance in the science of intra-academic principles and forms of theorization associated with the gradual generalization of empirical material in certain areas, which prevents it from reaching a higher level of abstraction. We face the paradox in which the branch directions (economic geography, geography of population and resettlement, political geography, etc.) today have a better proved, drawn up and represented methodology than the science which unifies them - social geography. Human geography in the conditions of its scientific potential and experience needs to solve this problem and, consequently, such a structured system of scientific laws has to appeal to those worldview and civilizational circumstances of scientific development which exist outside the boundaries of social geography. Taking into account the above conditions will facilitate the transition of human geography to a new scientific activity paradigm as a science of geospatial self-organization of society, its types, forms and relations. That very activity paradigm of geospatial relations, in our opinion, via their specific relations system (geo-economic, geo-social, geopolitical, geo-spiritual) will provide further assured development (without any trespassing on adjacent social sciences) of the four fundamental components of social geography - economic, social, political geography and cultural geography. For their part, today, they already have the established indisputable specific areas of cognition (subjects of research) and can contribute to the transformation of their own theoretical concepts as components of a wider scientific social and geographical world picture.

4. Changes in specific objects and subjects of modern human geography are generated by the informatization processes; they differ from the objects of industrial society research, production processes, etc. 
First of all, they deal with the information economy, information and communication infrastructure, network forms of economic activity organization, the information society as a whole and the phenomena it results in. In the process of Ukraine's transition to the information society, national human geography will not remain a landmark science of industrial society and will not go back to the past.The changes and challenges of the information society concern the foundations of social geography: the subject-object area is expanding (comparatively new directions are developing - quality of life geography, geography of social problems, perceptual, gender, electoral, sacral geography, etc., new methodological approaches are used (behavioural, synergetic); the methodological apparatus of social and geographical research is being improved (Mezentsev, 2010).

Consequently, in the absence of a core system of logically complete scientific laws, we face infringement of adjacent social sciences on the subject field of social geography, via their regional directions, as well as the tendencies of departure from actual social and geographical research as social geographers become embroiled in the aspects of adjacent social sciences and, accordingly, spatial analysis of these aspects. All this can lead to the decrease of positive trends in the development of socio-geographical science.The way out of the situation is seen in the consolidation of scientific-educational research and school-groups on the activation of theoretical and methodological developments. Promising in this regard are the geospatial-time theory, the theory of geospatial organization of society and the theory of territorial systems that will provide the theoretical substantiation of geospatial self-organization of society as an appropriate complex (system) that has regional (geospatial) differences and needs management. In such conditions, the results of the science will become popular in society, and therefore the status of human geography will increase, it will become more popular.

5. From the above follows another problem of the development of scientific schools in human geography- the failure of its application function. According to K. Mezentsev, a significant part of sociogeographical research in Ukraine is devoted to the study of traditional objects by traditional methods. Many socio-geographical works are based on outdated methodology and are characterized by scientific formalism, while other studies reveal a «theory for theory», where new terminological constructs, alternate complexes and systems do not result in any useful conclusions. Unsuccessful, according to the scientist, are the attempts at artificial «dragging» of the classical geography of production methodology (eco- nomic geography) into modern service, information and communication and network objects of research. Therefore, such challenges are connected with the non-recognition of the practical value of socio-geographical research. In view of the various reasons, the implementation of the science constructive potential is limited enough; there are no real government orders for the scientific development of regional forecasts, programmes, schemes, etc.

The theories we talked about above, taking into account the developments of human geography in Ukraine and the new ideas of the development of world science, should become the methodological basis of social geography, and most importantly - give it the opportunity to realize its constructive function in improving the processes of human life. The processes of complex and system formation are manifested in the territorial self-organization of all spheres of human activity, the emergence and expansion of socioeconomic relationships and relations, the transformation of the natural environment, the consolidation of territorial communities of people.Territorial centres are formed, all spheres of human life there are interconnected and they are included in the processes of social functioning, development and reproduction. The territorial self-organization of society has the properties of differentiation and discretization, which manifest themselves in the form of the administrativeterritorial structure and the system of regions of different taxonomic rank. Regional units of any level of the hierarchy are self-organized territorial systems that are specifically implemented in the socio-geographical space and historical time. It is precisely in order to improve the spatial self-organization of society that a system of bodies of state power and local self-government is formed, it enables the optimal combination of state administration and market regulation. Public geography in these conditions is intended to provide the theoretical and applied bases of territorial administration - management of the regions' development, to develop the scientific basis for the implementation of regional policy and the mechanism of its prediction.

Public geography, despite having a solid theoretical framework and concrete results of research in terms of improvement of various aspects of the territorial self-organization of society in Ukraine or its regions, cannot reach a qualitatively new level of its development, declare itself as a science, and, above all, cannot yet effectively solve a number of strategic issues of Ukraine's development in the context of its Eurointegration strategy. As O. Topchiiev observes, this is due to the small «mass» of social geographers in the state's scientific potential. Such problem can be solved only by the powerful scientific schools, which 
have to integrate their efforts to produce the specialists in the field of human geography of the highest level of qualification. Scientific and education institutions and schools should build a strategy of dragging into the plane of their research a number of applied directions that have formed on the boundaries of human geography and other sciences and have the potential to implement the constructive function of socio-geographical science. First of all, it deals with geo-economics, geo-politics, geo-ecology, geo-informatics, and so on. Scientists should transfer qualitative and quantitative results of their research to the achievements of these studies on the plane of human geography- a unified science, the methodology of which is really based on the principles of territorial analysis of the self-organization of all spheres of society's life.

If we talk about the strategic directions of research development within these components, we should say that only geo-economics has already adapted to market conditions the theory of economic zoning and the theory of TPCs, the concept of PGC, which can offer results in terms of increasing the competitiveness of regions, industrial specialization and balanced development of regions, justify market infrastructure creation, territorial organization of industries and outline the growth poles. The examples of such implementation of research are doctoral theses by G. Pidhrushnyi «Industry and Regional Development of Ukraine (theory and practice of socio-geographical research)», Yu. Palekha, «Theory and Practice of Determining the Value of Territories and Estimating the Lands of Settlements of Ukraine (economic and geographical research)», S. Zapototskyi «Scientific Principles of Regional Competitiveness Formation: socio-geographical research», I. Pylypenko «Center-peripheral Processes and Structures in the Territorial Organization of Society», etc.

Based on the experience of comprehensive and systematic study of territorial human communities, human geography has already successfully investigated the quality of population's life at the level of doctoral researches (I. Hukalova, «Quality of Population's Life in Ukraine: Theoretical and Methodological Foundations of Socio-Geographical Research») and the problem of depression in the development of territories (M. Baranovskyi «Rural Depressive Territories of Ukraine: Theoretical and Methodological Principles of Socio-Geographical Research»), geography of culture (I. Rovenchak «Geography of Culture: Problems of Theory, Methodology and Research Methods»), geosophia (Yu. Kyseliov «SocioGeographical Foundations of Theoretical and Applied Geosophical Researches in Ukraine»), geo-demography (V. Yavorska «Regional Geodemographic Processes in Ukraine: Theoretical and Methodological
Aspects»), which has prospects for studying human spatio-temporal behaviour.

The research, carried out by the staff of the IG NAS of Ukraine under the leadership of L. Rudenko, is devoted to the analysis of the problem of interaction of nature and society in Ukraine in the twentieth century, demonstrates a successful synthesis of natural, socio-geographical knowledge and ecology, at the same time, it reveals the great possibilities of geographers in the development of geo-ecology problems, theoretically substantiates the processes of interaction of society and nature, the formation of the natural life environment. The fundamental nature of this research area, its justification and the determination of the priorities for its further development can be found in the following dissertations: S. Lisovskyi «Economic and Geographical Principles of Sustainable Development of Ukraine», L. Nemets «Socio-Geographical Bases of the Transition Strategy of Ukraine to the Model of Sustainable Development», S. Sonko «Theoretical Foundations of the Spatial Sociogeospheric Systems Formation in the Context of the Sustainable Development Concept of Ukraine», K. Nemets «Socio-Geographical Foundations of Sociogeosystems' Information Development», etc.

The geopolitical direction is based on the political geography theory, territorial management and forecasting, regional policy and state studies, planning and spatial regulation, and is vividly represented in doctoral studies by M. Dnistrianskyi «Ethnopolitical Geography of Ukraine: Problems of Theory, Methodology, Practice» and P. Shukanov «Socio-Geographical Features of the Global Civilization Space Formation». We have solid work in the field of public administration as well, in particular, it deals the justification of principles of regional development management, regional development forecasting (K. Mezentsev, «Socio-Geographical Forecasting of Regional Development: Theory, Methodology, Practice»), geoplanning (D. Malchykova, «Methodology and Geoplanning Methodology of Rural Areas at the Regional Level»), geospatial studies and space planning practices (E. Maruniak, «Socio-Economic Space (Methodology of Geospatial Research and Planning Practice)».

Consequently, the above-mentioned directions are and will be developing in the plane of the human geography object-subject sphere. They strengthen its internal principles, supplement the science with new theses aimed at the discovery of new laws and regularities of territorial processes of the interaction between society and nature, spatial life organization, functioning and development of territorial systems, as well as new paradigms, hypotheses, concepts, methods and forms of their organization. The development 
of the principles of human geography will improve its methodology through the introduction of methods of geographic information systems and technologies, methods of spatial research, neural networks, mental mapping, etc. (Shevchuk,2017). On the other hand, such directions will promote the implementation of the applied function of science, related to the development of practical recommendations for improving the territorial self-organization of society.

Conclusions. Further realization of these tendencies in the national human geography requires clarification of its theoretical base in accordance with the realities of the beginning of the XXI century, at the same time it will contribute increased attention to the applied aspects of science and will protect it from pointless abstraction. The demands of society will influence the development of social geography, of course. In fact, these are the problems that require the immediate solution of scientific schools. The strategic goal is the determination of the economic, demographic, social, political and environmental capacities of the geographic shell, justification of rational parameters of regional and global nature management.The identification of the main trends of technological, sectoral and territorial development of the economy of Ukraine and its regions matter greatly. Raising the level and quality of life of Ukrainians; radical improvement of the technological structure of production and its transfer to an innovative level; definition and achievement of the optimal (for the modern stage of development of the country) social, functional-branch and territorial structure of the economy; optimization of the structure of economic, social, political and other relations are also considered to be the main tasks as well. The tasks of more active participation in solving the problems of nature use and conservation, the development of depressed regions, substantiation and implementation of regional economic, social, demographic and environmental policies are set before human geography at the regional and local levels. The key to solving these problems from the methodological point of view is the substantiation (using both domestic and world experience) of the general theory of regional studies taking into account the diversity of society's territorial organization.

\section{References}

Bahrov, N. V., 2005. Heohrafyia v ynformatsyonnom myre [Geography in the Information World]. Kiev. (in Russian).

Gudzevich, A. V., 2016. Prostorovo-chasova paradyhma v heohrafii: etapy stanovlennia ta rozvytku [Space- time paradigm in geography: stages of formation and development]. Ukrainian Geography: Modern Challenges. Vol. 1. 14-17. (in Ukrainian).

Dnistrianskyi, M. S., 2016. Pro neobkhidnist novoho pohliadu na predmet suspilnoi heohrafii [On the need for a new look at the subject of human geography]. Ukrainian Geography: Modern Challenges. Vol. 1. 26-28. (in Ukrainian).

Masliak, P. O., 2016. Zahalnoheohrafichna diisnist [General geographic reality]. Ukrainian Geography: Modern Challenges. Vol. 1. 52-53. (in Ukrainian).

Mezentsev, K. V., 2010. Ukraynskaia sotsyalnoэkonomycheskaia heohrafyia $\mathrm{v}$ nachale XXI v.: vыzovы у yzmenenyia [Ukrainian socioeconomic geography at the beginning of the XXI century: challenges and changes]. Theory of socio-economic geography: current state and development prospects. $352-356$. (in Russian).

Oleshchenko, V. I., 2016. Nevidkladni kroky shchodo zabezpechennia utverdzhennia suspilnoi znachushchosti heohrafii ta rozvytku yii teoretychnykh zasad [Steps to ensure the confirmation of the social significance of geography and the development of its theoretical foundations.]. Ukrainian Geography: Modern Challenges. Vol. 1. 63-65. (in Ukrainian).

Oliinyk, Ya. B., 2009. Stratehiia rozvytku ekonomichnoi i sotsialnoi heohrafii [Strategy of development of economic and social geography]. Human geography. Vol. 7. 6-15. (in Ukrainian).

Oliinyk, Ya. B., 2016. Tendentsii rozvytku heohrafichnoi nauky [Trends in the development of geographic science]. Economic and social geography. Vol. 75. 3-6. (in Ukrainian).

Rudenko, L. H., 2006. Novye zadachy heohrafyy na puty $\mathrm{k}$ ynformatsyonnomu obshchestvu [New tasks of geography on the way to the information society]. Ukrainian Journal of Geography. Issue 4. 15-19. (in Russian).

Topchiiev, O. H., 2016. Metodolohichni transformatsii predmetnoi oblasti vitchyznianoi heohrafii [Methodological transformations of the subject area of domestic geography]. Ukrainian Geography: Modern Challenges. Vol. 1. 106-108. (in Ukrainian).

Topchiiev, O. H., 2012. Novitni suspilni zapyty i napriamy metodolohichnoi transformatsii vitchyznianoi heohrafii [Newest public queries and directions of methodological transformation of national geography]. Ukraine: Geography of Goals and Opportunities. Vol. 3. 393- 399. (in Ukrainian).

Shablii, O. I., 2008. Imperatyv ukrainotsentryzmu v natsionalnii suspilnii heohrafii [The Imperative of Ukrainocentrism in the National Social Geography]. Geography in Information Society. Issue 4 (2). 3-5. (in Ukrainian).

Shevchuk, S. M., 2017. Suspilna heohrafiia v Ukraini : teoriia ta praktyka doslidzhen [Human geography in Ukraine: Theory and Practice of Research]. Poltava. (in Ukrainian). 